\title{
Effective Management of Purple Blotch of Onion Caused by Alternaria porri (Ellis) Through Host Resistance, Fungicides and Botanicals
}

\author{
Priyanka Jhala*, B.L. Mali and M.K. Meena \\ Department of Plant Pathology, Rajasthan College of Agriculture, MPUAT, Udaipur, India \\ *Corresponding author
}

\author{
A B S T R A C T
}

\begin{tabular}{|l|}
\hline Ke y w o r d s \\
Purple blotch, \\
Onion, Host \\
resistance, \\
Fungicides, \\
Botanicals. \\
\hline Article Info \\
\hline $\begin{array}{l}\text { Accepted: } \\
17 \text { April } 2017 \\
\text { Available Online: } \\
10 \text { May } 2017\end{array}$ \\
\hline
\end{tabular}

An experiment for the management of purple blotch of onion (Allium cepa L.) caused by Alternaria porri (Ellis) was carried out in Department of Plant Pathology, Rajasthan College of Agriculture, Udaipur during 2014-2015.Among 5 cultivars evaluated Nasik red showed susceptibility and Agri found light red showed resistance reaction against $A$. porri infection. Out of the six fungicides tested in vitro, Difenaconazole completely inhibited the mycelial growth of $A$. porri at concentration of 250, 500, 1000 and $2000 \mathrm{ppm}$, followed by Tebuconazole at 1000 and $2000 \mathrm{ppm}$. Neem formulations Azadirachtin was found effective in vitro followed by Garlic extract and Neem oil proved to be least inhibitor. Under pot culture study, combination of Difenaconazole and Azadirachtin was found most effective when applied as foliar spray. The application of fungicide and botanical resulted in significantly great disease control, over their individual applications as well as over untreated control. It would therefore, be desirable to apply integrated management practices to reduce the chances of development of resistance against fungicides, for effective and sustainable management of purple blotch of onion.

\section{Introduction}

Onion (Allium cepa L.) is one of the oldest bulb crop belongs to family Amaryllidaceae. It contains a phytochemical called quercetin, which is effective in reducing the risk of cardiovascular diseases, an anticancer and has promise to be an antioxidant (Smith, 2003). It is one of the most important vegetable cum condiment crop grown throughout the world. India occupies second rank in productivity next to China with an area of 12.04 lakh hectares with an annual total production of 194.02 lakh tons and an average productivity of $16.1 \mathrm{mt} / \mathrm{ha}$. In Rajasthan, it is cultivated in 5.75 lakh hectares with a total production of 7.05 lakh tons and productivity of $12.3 \mathrm{mt} / \mathrm{ha}$ (Anonymous, 2013-14).
Diseases can affect it at production, harvesting, processing and marketing, which lower the quality, reduce the yield, and thereby increase the cost of production, and also, the export potential.

Among the various foliar diseases of onion, purple blotch caused by Alternaria porri is one of the most destructive diseases, due to this disease yield loss ranging from 2.5 to 87.8 per cent during Kharif season (Shrivastava et al., 1994). The fungus attacks both leaves and flower stalk (Bock, 1964), reducing foliar production by 62-92\% (Suheri and Prince, 2001). The yield loss of onion in India due to this disease under favorable 
conditions varies from 5.0 to 96.5 per cent (Gupta and Pathak, 1988) and 97 per cent (Lakra, 1999).

Keeping in view of the above reason management of purple blotch of onion has become a issue in present condition. In this regard experiments were carried out to test different fungicides and botanicals for their effectiveness against the pathogen and to identify the resistant variety against purple blotch of onion.

\section{Materials and Methods}

\section{Evaluation of onion cultivar for host plant resistance}

The culture of A. porri was used for study the host plant resistance against purple blotch of onion, 5 onion cultivars viz., Poona red, Agri found dark red, Agri found light red, Nasik red and Prema were evaluated under artificial inoculated conditions. Experiment was laid out in completely randomized design (CRD) with five replications under cage house conditions in earthen pots. The one month old seedlings of onion varieties were transplanted in pots. After attaining the age of 50 days from date of transplanting, the plants were inoculated with spore cum mycelial suspension of pathogen. High humidity was maintained by spraying with water and covering the inoculated plants with polythene bags. The observations on per cent disease intensity were recorded after 10 days of inoculation using 0-5 disease rating scale. The varieties were categorized according to their host reaction against the disease as per criterion followed by Pathak et al., (1986).

\begin{tabular}{|l|l|l|}
\hline S.No. & PDI Range & Reaction \\
\hline 1. & $<5 \%$ & Immune \\
\hline 2. & $5 \%$ to $10 \%$ & Resistant \\
\hline 3. & $11 \%$ to $20 \%$ & Moderately Resistant \\
\hline 4. & $21 \%$ to $40 \%$ & Moderately Susceptible \\
\hline 5. & $41 \%$ to $60 \%$ & Susceptible \\
\hline 6. & More than $61 \%$ & Highly Susceptible \\
\hline
\end{tabular}

The per cent disease index (PDI) was calculated using following formula given by Wheeler (1969):

Sum of all individual disease rating
Percent disease index $(\mathrm{PDI})=$ Total No. of plant assessed $\times$ Maximum rating

\section{Management of disease}

Management of disease was undertaken in vitro and in pot, under cage house natural conditions.

In vitro efficacy of fungicides against $A$. porri

Six fungicides viz., Carbendazim 50\% WP [Methyl-2 benzimidazole carbamate (MBC)]
BASF India Ltd., Mumbai. Dithane M-45 75 $\%$ WP [Mancozeb, Indofil M-45 75\% WP, Mangnese ethylene bis- dithiocarbamate plus zinc lons 2\%] Indofil chemicals Ltd., Mumbai. difenaconazole 25\% EC [Score, 1[2-[2-chloro-4-(4-chloro-phenoxy)-phenyl]-4methyl[1,3]dixolan-2-methyl]-1H-1,2,4triazole] Syngenta India Ltd., Pune. Fluopyram 500SC [LUNA Privilege, N-\{2[3-chloro-5-(trifluromethyl)-2-pyridyl]ethyl\}$\alpha, \alpha, \alpha$-trifluoro- $o$-tolumide] Bayer crop 
science, India Ltd., Mumbai. tebuconazole 430SC [1 - (4- chlorophenyl) - 4, 4- dimethyl - 3 - (1,2,4 - triazol-1-1 methyl) pentan -301] Bayer crop science, India Ltd., Mumbai. pristine 38\% WG (pyraclostrobin $12.8 \mathrm{WG}+$ boscalid 25.2 \%WG) BASF India Ltd., Mumbai were evaluated in vitro against $A$. porri by poisoned food technique (Nene and Thapaliyal, 1993) at four concentrations viz., 250, 500, 1000 and $2000 \mathrm{ppm}$.

The calculated quantities of fungicides were thoroughly mixed in the PDA medium before pouring into Petri-plates. Twenty $\mathrm{ml}$ of fungicide amended medium was poured in each $90 \mathrm{~mm}$ sterilized Petri plates and allowed to solidify. The plates were aseptically inoculated with $5 \mathrm{~mm}$ disc cut from the periphery of 7 days old cultures of $A$. porri and controls without fungicides were maintained for comparison. The experiments were conducted in completely randomized design (CRD) with three replications in each treatment and the inoculated plates were incubated in BOD incubator at $25 \pm 1^{\circ} \mathrm{C}$. The colony diameter was measured after 7 days when the control plates were full of fungal growth. Per cent inhibition of mycelial growth was calculated by using formula given by Vincent (1947) as:

$\mathrm{I}=\frac{\mathrm{C}-\mathrm{T}}{\mathrm{C}} \times 100$

Where,

$\mathrm{I}=$ Per cent inhibition

$\mathrm{C}=$ Colony diameter in control; $\mathrm{T}=$ Colony diameter in treatment

\section{In vitro evaluation of different botanicals}

Efficacy of two Neem based formulations viz., Azadirachtin (2\% and 4\%), Neem oil ( $2 \%$ and $4 \%$ ), developed by Godrej Agrovet Pvt. Ltd., Mumbai, for commercial purpose and Garlic extract (2\% and 4\%) of plant origin were tested against $A$. porri by poisoned food technique. The calculated quantities of formulations were incorporated in PDA to obtain desired concentration (2 per cent and 4 per cent) and then PDA was dispensed in sterilized $90 \mathrm{~mm}$ glass Petriplates under aseptic conditions, for comparison PDA without Neem formulations and Garlic extract kept as control. For each treatment of botanicals four replications were taken. Each Petri plate was aseptically inoculated by placing $5 \mathrm{~mm}$ diameter disc cut from the periphery of 7 days of old cultures of A. porri and controls without botanicals were maintained for comparison. The plates were incubated in BOD incubator at $25 \pm 1^{\circ} \mathrm{C}$ for 7 days and then colony diameters were measured and compared with control plates where the respective pathogen was grown on PDA without Neem formulations and Garlic extract.

\section{Evaluation of fungicides and botanicals for management of purple blotch of onion}

The best effective fungicides found in vitro were assessed alone and in combination with Azadirachtin that was most effective botanical in vitro against $A$. porri as spray application for management of purple blotch of onion. The experiment was conducted in pots (30 $\mathrm{cm}$ ) in completely randomized design (CRD) with five replications in cage house. The pots were filled with sand, soil and FYM (3:1:1 mixture) raising plants for the experiment. For each treatment, seedlings of onion local land race were sown and maintaining 4 plants per pot.

Solution of Difenaconazole $(0.025 \%)$ and Azadirachtin (4\%) alone and combination of fungicides (Difenaconazole) and botanicals (Azadirachtin) found most effective in vitro were sprayed twice first after $24 \mathrm{hrs}$ of inoculation and second at 15 days interval. Spray inoculations were made as described 
earlier. For comparison inoculated control was maintained without fungicidal/botanical application. Observations of disease severity were recorded after 10 days of inoculation on a standard disease rating scale 0-5 score and per cent disease index (PDI) was calculated using formula described earlier.

The per cent efficacy of disease control (PEDC) was calculated by using following formula given by Chester, 1959 and Wheeler, 1969:

PDI in control - PDI treatment

PEDC $=-\frac{\text { PDI in control }}{\text { P }} 100$

\section{Results and Discussion}

\section{Host plant resistance}

Host plant resistance is considered to be a dependable and eco-friendly disease management strategy. Agrifound dark red and Prema were found moderate resistant with mean PDI of 13.78 and 12.80 respectively. Agrifound light red found to be resistance with mean PDI of 9.37, Poona red found to be moderately susceptible with mean PDI of 32.24 and Nasik red with maximum mean PDI of 49.16 showed susceptibility to purple blotch of onion. However, Sharma and Sain (2003) described RO-1, a newly-developed onion cultivar for cultivation under the agroclimatic zone of Rajasthan, India, which is resistant to purple blotch of onion. Mathur et al., (2006) describe onion cv. RO 59 has shown resistance to purple blotch. Chethana et al., (2011) conducted screening of onion genotypes for purple blotch of onion under field condition revealed that, the genotype Arka Kalyan was found moderately resistant while the genotypes viz., Rampur Rose, Agrifound Rose, Arka Pragati, Arka Niketan, Arka Pitamber and Arka Bindu were found moderately susceptible to purple blotch of onion. Similar studies were carried out by Munoz and Parts (2004); Razdan et al., (2008); Tripathi et al., (2013); Behra et al., (2013) and Haq et al., (2014).

\section{In vitro evaluation of fungicides (Poisoned food technique)}

All the tested fungicides significantly inhibited the mycelial growth of $A$. porri at all concentrations i.e. 250, 500, 1000 and 2000 ppm.

Difenaconazole inhibited 100 per cent mycelial grow that $250 \mathrm{ppm}$ concentration. Similarly at 500, 1000 and 2000 ppm concentrations it inhibited 100 per cent growth.

Tebuconazole at $250 \mathrm{ppm}$ concentration inhibited 86.67 per cent of mycelial growth of the pathogen followed by Pristine, Fluopyram, Mancozeb and Carbendazim that caused $83.89,71.11,60.56$ and 20.56 per cent inhibition of mycelial growth respectively.

Tebuconazole caused 88.89 per cent inhibition of growth at $500 \mathrm{ppm}$ while at 1000 and $2000 \mathrm{ppm}$ concentrations it caused 100 per cent inhibition of growth. Similarly Pristine at 500, 1000 and 2000 ppm concentrations caused 85.56, 86.11 and 87.22 per cent inhibition of growth followed by Fluopyram which caused 75.00, 77.77 and 79.44 per cent inhibition of growth, respectively.

Mancozeb inhibit 66.22 and 74.44 per cent growth at 500 and 1000 ppm concentrations respectively, while at $2000 \mathrm{ppm}$ concentration it caused 100 per cent inhibition of growth. Least inhibition was observed in Carbendazim at all concentrations and it caused 39.44, 43.89 and 58.33 per cent inhibition of growth at 500, 1000 and $2000 \mathrm{ppm}$ concentrations, respectively. Wanggikar et al., (2014) tested 
the fungicides; among fungicides in Hexaconozole cent per cent $(100 \%)$ inhibition was observed, followed by Difenaconazole (83.91\%) and Mancozeb (63.58\%). Chethana et al., (2011) tested three nonsystemic and three systemic fungicides against $A$. porri causing purple blotch of onion under in-vitro conditions. Among systemic fungicides tested Difenaconazole at 0.1 per cent showed 98.85 per cent inhibition of the fungus followed by Kitazin while among the non-systemic fungicides Mancozeb at 0.3 per cent was best in inhibiting the growth of A. porri with 100 per cent inhibition followed by Iprodione. Yadav et al., (2013) were tested different concentrations of systemic fungicides in vitro and reveled that Hexaconozole was found most effective with highest mean inhibition of radial growth $(98.21 \%)$ followed by Propiconazole $(97.32 \%)$ and Difenaconazole $(91.23 \%)$ (Table 1).
In vitro evaluation of botanicals (Poisoned food technique)

All the test botanicals significantly inhibited the mycelial growth of pathogen. Azadirachtin caused maximum inhibition of linear growth (62.09 and $68.61 \%)$ of pathogen at 2 and 4 per cent concentrations followed by Garlic extract (53.13 and 57.42\%), while Neem oil was found to be least effective at 2 and 4 per cent concentrations caused minimum inhibition (45.39 and 52.18\%).

Chethana et al., (2012) was evaluated bioefficacy of six plant products (Clerodendron, Cinnamon, Garlic, Neem oil, Pongamia oil and Turmeric), under in vitro conditions (Table 2).

Table.1 In vitro study of various fungicides against Alternaria porri at 250, 500, 1000 and 2000 ppm concentrations after 7 days at $25 \pm 1^{\circ} \mathrm{C}$ (poisoned food technique)

\begin{tabular}{|c|c|c|c|c|c|c|c|c|}
\hline \multirow[t]{2}{*}{ Treatments } & \multicolumn{4}{|c|}{$\begin{array}{c}\text { Colony diameter }(\mathrm{mm}) * \\
\text { Concentration }(\mathrm{ppm})\end{array}$} & \multicolumn{4}{|c|}{$\begin{array}{l}\text { Per cent growth } \\
\text { Inhibition** }\end{array}$} \\
\hline & 250 & 500 & 1000 & 2000 & 250 & 500 & 1000 & 2000 \\
\hline Difenaconazole & 0.00 & 0.00 & 0.00 & 0.00 & $\begin{array}{r}100.00 \\
(90.00) \\
\end{array}$ & $\begin{array}{l}100.00 \\
(90.00) \\
\end{array}$ & $\begin{array}{l}100.00 \\
(90.00) \\
\end{array}$ & $\begin{array}{l}100.00 \\
(90.00) \\
\end{array}$ \\
\hline Tebuconazole & 12.00 & 10 & 0.00 & 0.00 & $\begin{array}{c}86.67 \\
(68.59)\end{array}$ & $\begin{array}{c}88.89 \\
(70.53)\end{array}$ & $\begin{array}{c}100 \\
(90.0)\end{array}$ & $\begin{array}{c}100 \\
(90.0)\end{array}$ \\
\hline Pristine & 14.50 & 13 & 12.50 & 11.50 & $\begin{array}{c}83.89 \\
(66.34)\end{array}$ & $\begin{array}{c}85.56 \\
(67.67)\end{array}$ & $\begin{array}{c}86.11 \\
(68.12)\end{array}$ & $\begin{array}{c}87.22 \\
(69.06)\end{array}$ \\
\hline Fluopyram & 26.00 & 22.50 & 20.00 & 18.50 & $\begin{array}{c}71.11 \\
(57.49)\end{array}$ & $\begin{array}{c}75.00 \\
(60.00)\end{array}$ & $\begin{array}{c}77.78 \\
(61.88)\end{array}$ & $\begin{array}{c}79.44 \\
(63.04)\end{array}$ \\
\hline Mancozeb & 35.50 & 30.40 & 23 & 0.00 & $\begin{array}{r}60.56 \\
(51.10) \\
\end{array}$ & $\begin{array}{c}66.22 \\
(54.47) \\
\end{array}$ & $\begin{array}{r}74.44 \\
(59.63) \\
\end{array}$ & $\begin{array}{c}100 \\
(90.0) \\
\end{array}$ \\
\hline Carbendazim & 71.50 & 54.50 & 50.50 & 37.50 & $\begin{array}{c}20.56 \\
(26.93)\end{array}$ & $\begin{array}{c}39.44 \\
(38.89) \\
\end{array}$ & $\begin{array}{c}43.89 \\
(41.49)\end{array}$ & $\begin{array}{c}58.33 \\
(49.80) \\
\end{array}$ \\
\hline Control & 90.00 & 90.00 & 90.00 & 90.00 & 0.00 & 0.00 & 0.00 & 0.00 \\
\hline $\begin{array}{l}\text { Fungicide } \\
\text { Isolate } \\
\text { F X I } \\
\text { CV }(\%)\end{array}$ & $\begin{array}{l}\text { SEm } \pm \\
0.32 \\
0.24 \\
0.63 \\
3.73\end{array}$ & $\begin{array}{l}\mathrm{CD} \\
0.8 \\
0.6 \\
1.7 \\
1.8\end{array}$ & at $5 \%$ & $\begin{array}{l}\text { SEm } \\
0.35 \\
0.27 \\
0.70\end{array}$ & & $\begin{array}{l}\mathrm{D} \text { at } 5 \% \\
.99 \\
.75 \\
.99\end{array}$ & & \\
\hline
\end{tabular}

*Mean of three replications

Figures in parentheses are arcsine $\sqrt{ }$ per cent angular transformed values 
Table.2 In vitro study of various botanicals against Alternaria porri at 2 and 4 per cent concentrations after 7 days at $25 \pm 1^{\circ} \mathrm{C}$ (poisoned food technique)

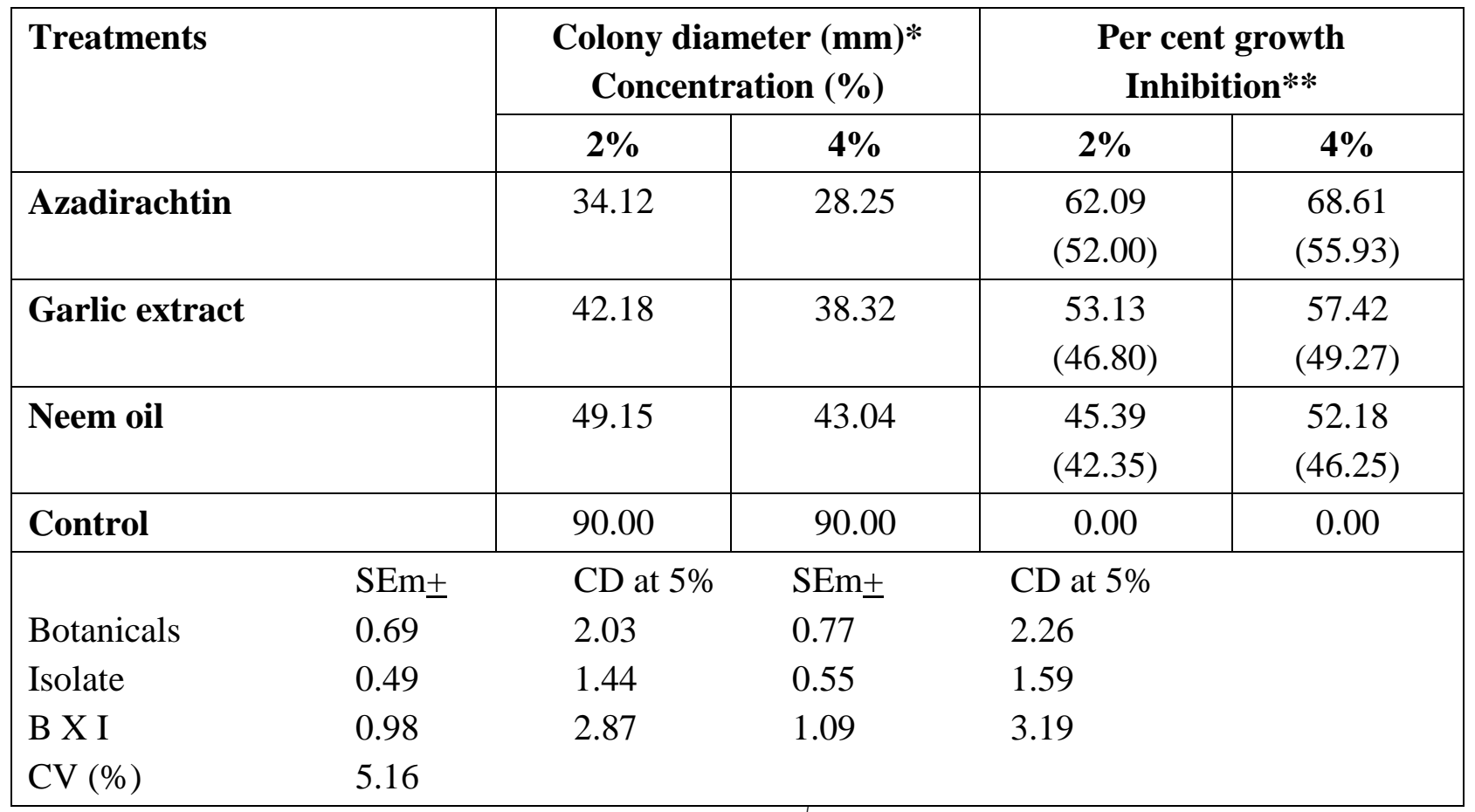

* Mean of four replications; Figures in parentheses are arcsine $\sqrt{ }$ per cent angular transformed values

Table.3 Relative efficacy of foliar spray of promising fungicides/ botanicals/ fungicides + botanicals on Purple blotch in pot culture

\begin{tabular}{|l|l|c|c|c|}
\hline S.No. & $\begin{array}{l}\text { Fungicide, botanical and their combination } \\
\text { with concentration doses (\%) }\end{array}$ & $\begin{array}{c}\text { Per cent disease } \\
\text { index (PDI)* }\end{array}$ & (PEDC)** \\
\hline 1. & Difenaconazole & $0.025 \%$ & 26.04 & 60.15 \\
& & $(30.68)$ & $(50.81)$ \\
\hline $\mathbf{2 .}$ & Azadirachtin & $4.0 \%$ & 47.28 & 27.64 \\
& & $(43.44)$ & $(31.66)$ \\
\hline $\mathbf{3 .}$ & Difenaconazole+ & $0.025 \%+4.0 \%$ & 20.03 & 69.35 \\
& Azadirachtin & $(26.58)$ & $(56.35)$ \\
\hline $\mathbf{4 .}$ & Control & 65.34 & 0.00 \\
& & $(53.97)$ & $(0.00)$ \\
\hline & SEm \pm & 0.88 & 0.81 \\
& CD $(\mathrm{P}=0.05)$ & 2.59 & 2.39 \\
& CV $(\%)$ & 4.41 & 4.11 \\
\hline
\end{tabular}

*Mean of five replications;

** Per cent efficacy of disease control

Figures in parentheses are arcsine $\sqrt{ }$ per cent angular values; 
Table.4 Disease severity and reaction of different onion cultivars to Alternaria porri

\begin{tabular}{|l|l|c|c|}
\hline S.No. & Onion cultivars & \multicolumn{2}{|c|}{ Disease severity (PDI)* } \\
\hline 1. & Nasik red & 49.16 & $(44.52)$ \\
& & 32.24 & $(\mathrm{MS})$ \\
\hline 2. & Poona red & $(34.59)$ & $(\mathrm{MR})$ \\
\hline 3. & Agrifound dark red & 13.78 & $(\mathrm{R})$ \\
& & 9.37 & $(\mathrm{MR})$ \\
\hline 4. & Agrifound light red & $(17.82)$ & \\
\hline 5. & Prema & $(20.96)$ & \\
& & 0.63 & \\
\hline & $\mathrm{SEm} \pm$ & 1.86 & 5.37 \\
& $\mathrm{CD}(\mathrm{P}=0.05)$ & & \\
& $\mathrm{CV}(\%)$ & & \\
\hline
\end{tabular}

*Mean of five replications

S: Susceptible, MS: Moderate susceptible, MR: Moderate resistant, R: Resistant

Figures in parentheses are arcsine $\sqrt{ }$ per cent angular transformed values

Among plant products evaluated, fresh aqueous extract of Garlic (20\%) was effective in causing 100 per cent inhibition of mycelial growth. Neem oil and Pongamia oil (20\%) caused 76.94 and 69.94 per cent inhibition. Various botanicals have been attempted against Alternaria porri (Tiwari and Srivastava, 2004; Meena 2012; Abdel-Hafez et al., 2014).

Evaluation of fungicides and neem formulations in vivo against Alternaria porri on susceptible cultivar

The best effective fungicides and botanical found in vitro were assessed alone and in combination against $A$. porri as spray application.

Maximum per cent efficacy of disease control (PEDC) 69.35 per cent was observed in combination of Difenaconazole $(0.025 \%)$ and Azadirachtin (4\%) with minimum per cent disease index (PDI) was 20.03 per cent as compared to $65.34 \mathrm{PDI}$ in the untreated control followed by the spray of Difenaconazole that exhibited 60.15 PEDC with 26.04 PDI, while Azadirachtin with 27.64 PEDC and 47.28 PDI were found effective as compared to 65.34 PDI in the untreated control. The differences in per cent disease control among all the treatments were statistically significant which showed less per cent disease index compared to control.

It can be inferred from the data that combination of Difenaconazole $(0.025 \%)$ and Azadirachtin (4\%) can be best remedy to control the purple blotch of onion. Deshmukh et al., (2008) evaluated eight different fungicides in controlling the purple blotch $(A$. porri) of onion under net house condition (pot trial). Maximum disease control (79.58\%) was recorded in foliar application of a mixture of Hexaconozole $(0.005 \%)+$ Mancozeb $(0.3 \%)$ followed by Difenaconazole $(0.025 \%)$ + Mancozeb $(0.3 \%)$ in reducing disease intensity $(70.72 \%)$, over the control. Saha et $a l .$, (2009) tested the Amistar (0.05 and 0.1\%) and Garlic extract (0.5 and $1.0 \%)$ against purple blotch found that Amistar @ 0.1 per cent and Garlic extract @1 per cent significantly reduced the percentage of leaf area infection (Tables 4 and 5). 
The disease can be thus, managed by combination of resistant variety and timely application of fungicides and botanicals. The present data of experiment are again confirmed and strongly supported the results obtained by earlier workers on this disease.

\section{References}

Abdel-Hafez, S.I.I., Abo-Elyousr, K.A.M. and Abdel-Rahim, I.R. 2014. Effectiveness of plant extracts to control purple blotch and Stemphylium blight diseases of onion (Allium cepa L.) in Assiut, Egypt. Arch. Phytopathol. Plant Protection, 47(3): 377-387.

Anonymous. 2013-14. National Horticulture Board.

Behera, S., Santra, P., Chattopadhyay, S., Das, S. and Maity, T.K. 2013. Variation in onion varieties for reaction to natural infection of $A$. porri (Ellis) Ciff. And $S$. vesicarium (Wallr.). The Bioscan, 8(3): 759-761.

Bock, K.R. 1964. Purple blotch (Alternaria porri) of onion in Kenya. Ann. Appl. Biol., 54: 303-311.

Chester, K.S. 1959. How sick is the plant in "Plant Pathology" and Ad. Tretise (Eds J.S. Horsfall and A.E. Diamond) Vol. I Ac. Press, New York. 99-142.

Chethana, B.S., Ganeshan, G. and Manjunath, B. 2011. Screening of genotypes and effect of fungicides against purple blotch of onion. Int. J. Agri. Technol., 7(5): 1369-1374.

Chethana, B.S., Ganeshan, G., Rao, A.S. and Bellishree, K. 2012. In vitro evaluation of plant extracts, bioagents and fungicides against Alternaria porri (Ellis) Cif. causing purple blotch disease of onion. Pest Management in Horticultural Ecosystems, 18(2): 194198.

Deshmukh, V.S., Chavan, R.V. and Deshmukh, C.D. 2008. Efficacy of fungicides in-vitro against Alternaria porri (Ellis) Cif. causing purple blotch of onion. J. Plant Dis. Sci., 3(1): 127128.

Deshmukh, V.S., Dhruj, I.U., Chavan, R.V. and Borgaonkar, S.B. 2008. A study to assess loss in seed yield of onion due to purple blotch disease caused by Alternaria porri (Ellis) Cif. Int. J. Plant Sci., (Muzaffarnagar), 3(2): 352-354.

Gupta, R.B.L. and Pathak, V.N. 1988. Yield losses in onions due to purple leaf blotch disease caused by Alternariaporri. Phytophylactica, 20: 21-23.

Haq, I.U., Zaman, Z., Habib, A., Javed, N., Khan, S., Iqbal, M. and Ihsan, J. 2014. Assessment of yield losses caused by purple blotch disease in onion (Allium cepa L.) and its management. Pak. J. Phytopathol., 26(02): 225-232.

Lakra, B.S. 1999. Development of purple blotch incited by Alternaria porri and its losses in seed crop of onion. Indian J. Agri. Sci., 69(2): 144-146.

Mathur, K., Sharma, S.N. and Sain, R.S. 2006. Onion Variety RO 59 has higher yield and resistance to purple blotch and Stemphylium blight. J. Mycol. Plant Pathol., 36(1): 49-51.

Meena, R.P. 2012. Bio-efficacy of plant extracts for management of purple blotch disease of onion (Allium cepa). Indian Phytopathol., 65(3): 253-257.

Munoz, L. and Prats, A. 2004. Caribe 71, an onion cultivar for tropical climate. Cultivos Tropicales, 25(3): 59-62.

Nene, Y.L. and Thapliyal, P.N. 1993. "Fungicides in plant disease control" Oxford and IBH Publishing co. Pvt. Ltd. New Delhi, 531.

Pathak, D.P., Singh, A.A., Despande and Sridar, T.T. 1986. Source of resistance to purple blotch in onion. Veg. Sci., 13(2): 300-303. 
Razdan, V.K., Shahnaz, E. and Kumar, S. 2008. Influence of weather parameters on purple blotch of onion. Indian Phytopathol., 61(1): 90-94.

Saha, A.K., Hossain, I., Monsur, M.A., Quais, M.K. and Akter, M. 2009. Effect of amistar and garlic extract in controlling purple blotch and storage diseases of onion. Bangladesh J. Plant Pathol., 25(1/2): 67-70.

Sharma, S.N. and Sain, R.S. 2003. RO-1 an improved onion variety for the warmer areas of Rajasthan. Indian J. Genetics and Plant Breeding, 63(3): 281-282.

Sharma, S.R. 1986. Effect of fungicidal on purple blotch and bulb yield of onion. Indian Phytopathol., 39: 78-82.

Shrivastav, P.K., Bharadwaj, B.S. and Gupta, P.P. 1994. Status of field diseases and selected pest of onion in India. National Horticulture Res. Deve. Found news Letter, 14: 11-14.

Smith, C. 2003. Genetic Analysis of Quercetin in Onion (Allium cepa L.) 'Laddy Raider'. The Texas J. Agri. Natural Res., 16: 24-28.

Suheri, H. Price, T.V. 2001. Purple leaf blotch disease of Allium spp. in Australia. Acta Horticulture, (555): 171-173.
Tiwari, B.K. and Srivastava, K.J. 2004. Studies on bio-efficacy of some plant extracts against pathogens of onion. News Letter - National Horticultural Res. Develop. Foundation, 24(1): 6-10. Tripathy, P., Priyadarshini, A., Das, S.K., Sahoo, B.B. and Dash, D.K. 2013. Evaluation of onion (Allium cepa L.) genotypes for tolerance to thrips (Thrips tabaci L.) and Purple Blotch [Alternaria porri (Ellis) Ciferri]. Int. J. Biores. Stress Management, 4(4): 561-564.

Vincent, J.M. 1947. Distortion of fungal hyphae in the presence of certain inhibitors. Nature, 159: 850.

Wanggikar, A.A., Wagh, S.S., Kuldhar, D.P. and Pawar, D.V. 2014. Effect of fungicides, botanicals and bioagents against purple blotch of onion caused by Alternaria porri. Int. J. Plant Protection, 7(2): 405-410.

Wheeler, B.E.J. 1969. An introduction to plant diseases. John Willey and Sons Ltd. London, 301.

Yadav, P.M., Rakholiya, K.B. and Pawar, D.M. 2013. Evolution of different systemic fungicides against Alternaria from in vitro. Trends in Biosci., 6(4): 382-383.

\section{How to cite this article:}

Priyanka Jhala and B.L. Mali. 2017. Effective Management of Purple Blotch of Onion Caused by Alternaria porri (Ellis) Through Host Resistance, Fungicides and Botanicals. Int.J.Curr.Microbiol.App.Sci. 6(5): 1737-1745. doi: https://doi.org/10.20546/ijcmas.2017.605.188 